One final chastening thought: most of the articles and letters that the $B M \mathcal{F}$ receives are written by doctors or relatives of doctors. How much worse do we sometimes handle those who are less well informed and articulate?

Associate editor, $B M \mathcal{F}$

TESSA RICHARDS

1 Williams A. Incurable illness. BMF 1990;301:67.

2 General Medical Council Education Committee. Recommendutions on basic medical education. London: GMC, 1980.
National Consumer Council. Consulting consumers in the NHS: a guideline study. London: NCC,

4 Winn L. Power to the people: the key to responsive services in health and sectial care. London: Kings Fund Centre, 1990

5 Savage R, Armstrong D. Effect of a general practitioner's consulting style on patients' satisfaction: a controlled study. B.MY 1990;301:968-70.

Ridsdale L, Carruthers $\mathrm{M}$, Morris R, Ridsdale J. Study of the effect of time availability on the consultation. I $R$ Coll (ien Pract 1989;39:488-91.

Office of Health Economics. People as patients and patients as people. London: OHE, 1989. $1 \mathrm{OHE}$ Symposium 5, July 1988 .

8 Hartnell L. Personal view. BMf 1987;294:1029.

9 Allen D. Thoughts from the other side of the sheets. BM7 1989;299:13.

10 Morton J Pershts from the other side of the

10 Morton J. Personal view. BMF 1987;295:1482.

\title{
Archives of contemporary medicine and science
}

\author{
Are important if we want historians to assess our times
}

No period of human history has seen so many advances in science and technology that have revolutionised medicine as the twentieth century. In the words of Sir Henry Dale in 1950, "Our successors ... are likely to recognise the first half of the twentieth century as the period in which civilisation first began to feel, for good or ill, the full impact of progress in the natural sciences." Since then the pace of scientific advance has quickened further, the new sciences of molecular and cell biology affecting both the principles and practice of medicine, to say nothing, for example, of the immunological revolution. It will be for historians to assess and analyse the ways in which medicine and its allied sciences have developed during this century, yet they can do so only if they have access to the source material. Are we paying enough attention to archives, or is our society discarding its history?

Until recently there has been little professional interest in the history of recent medical science. The Wellcome Trust, however, has now launched a new initiative to promote the historical study of twentieth century medical sciences. For historians, professional or amateur, the most important sources are contemporary records. These may include published work and the records of public bodies such as the Medical Research Council. But they also include the valuable information contained in correspondence, diaries, andparticularly - the original laboratory notebooks of individual scientists. Oral history and the recollections of individuals, as well as film, audio, and even machine readable material, all provide important subsidiary evidence. If the remarkable history of twentieth century medical science is to be pursued effectively, such archives and records must be professionally preserved.

Some of these archives are and will continue to be housed in well known repositories such as the Public Record Office. But few working papers of scientists seem to have survived. Scientists themselves, or more often their executors, commonly fail to appreciate the historical value of apparently routine or mundane material. Records emanating from government funded and research institutions are not always deemed to be public records, and even when scientific information is preserved it may be buried in administrative archives. Some academic bodies do, however, hold records of importance. For example, Sheffield University holds the papers of Sir Hans Krebs, and University College those of J Z Young, Karl Pearson, and Lionel Penrose. The personal papers of Sir Henry Dale and Lord Florey are housed at the Royal Society, and royal colleges and other institutions may preserve similar collections, including biographical information relating to their members or fellows, as well as their own archives. This apparently random disposition is often explained by the different acquisition policies of the various repositories.

\section{Introducing order}

An attempt to introduce some order and positive action to preserve papers of twentieth century scientists was the creation in 1973 of a Contemporary Scientific Archives Centre, set up in Oxford with the help of a grant from the Royal Society. Renamed the National Cataloguing Unit for Archives of Contemporary Scientists it is now based at the University of Bath. It does not retain archives but locates and catalogues papers of distinguished contemporary British scientists and engineers and advises on the placement of their collections in appropriate repositories.

The Wellcome Trust established the Contemporary Medical Archives Centre in 1979 as a component of the Wellcome Institute for the History of Medicine. The centre's collections include archives of organisations such as the Lister Institute and the Strangeways Laboratories, records of professional associations - for example, the British Pharmacological Society - and the personal papers of many medical scientists.

For the future, we hope that those in possession of papers will dispose of them to an established repository, where the material will be correctly stored, listed, and made available. It is not enough simply to hand over scientific collections to other individuals or small organisations. This may lead to confusion and will not always ensure adequate housing, access for historians, and, ultimately, the long term preservation of the material. While the records, archives, and personal papers of twentieth century literary and political figures are treasured, those of scientists, medical or otherwise, are undervalued and often neglected. If the history of twentieth century medical science is to be studied effectively its source materials must be preserved.

Harveian Librarian,

Royal College of Physiciàns,

London NW1 $4 \mathrm{LE}$

CHRISTOPHER BOOTH

Archivist,

Contemporary Medical Archives Centre,

Wellcome Institute for the History of Medicine, London NW1 2BN

Historian of 20th Century Medical Sciences, Wellcome Institute for the History of Medicine, London NW1 2BN

1 Dale HH. Advances in medical therapeutics. BMF 1950;i:1-7. 